\title{
MAFIC DYKES INTRUSIVE IN THE SÃO JOÃO DEL REI GROUP, MINAS GERAIS, BRAZIL
}

\author{
C.M.Noce ${ }^{1}$ \\ J.Karfunkel ${ }^{1}$
}

The São João del Rei Group is a metasedimentary sequence of Middle to Late Proterozoic age, overlying an Archaean granite-greenstone basement. This basement is intruded by Lower Proterozoic granodioritic bodies, and both have been cut by various sets of mafic dykes described by QUÉMÉNEUR (1989) in the Bom Sucesso region, west of the study area. The São João del Rei Group itself is cut by at least two different types of mafic dykes (Fig. 1).

\section{SCHISTOSE DYKES}

These are almost exclusively found in the Tiradentes Formation which makes up the Lenheiro and São José quartzitic ranges. The dykes are strike-concordant but cut across the country rocks at a high angle. They show a well developed schistosity and secondary mineralogy.

In the Lenheiro Range, west of São João del Rei, the dykes are subvertical and $\mathbf{3 0}$ $\mathrm{cm}$ to $5 \mathrm{~m}$ wide (VALERIANO, 1985). In thin section they are composed mainly of chlorite, quartz and magnetite. These dykes exhibit all the kinds of tectonic microstructures observed in the metasediments and are thus considered to be pretectonic.

The most striking of all the dykes is located in the northeastern São José Range (KARFUNKEL et al., 1984). It is about $3 \mathrm{~m}$ wide and dips $60^{\circ}$ to $70^{\circ} \mathrm{SE}$. The dyke is sulphide-rich showing centimetric crystals of pyrite associated with minor chalcopyrite and galena. It is also gold-

${ }^{1}$ Instituto de Geociências, Universidade Federal de Minas Gerais, Belo Horizonte, MG, Brazil. 
mineralized where it cuts across gold-bearing quartz veins. As such veins are probably related to the main metamorphic-tectonic event and as the dyke is slightly younger than the veins, the dykes must be of syntectonic character.
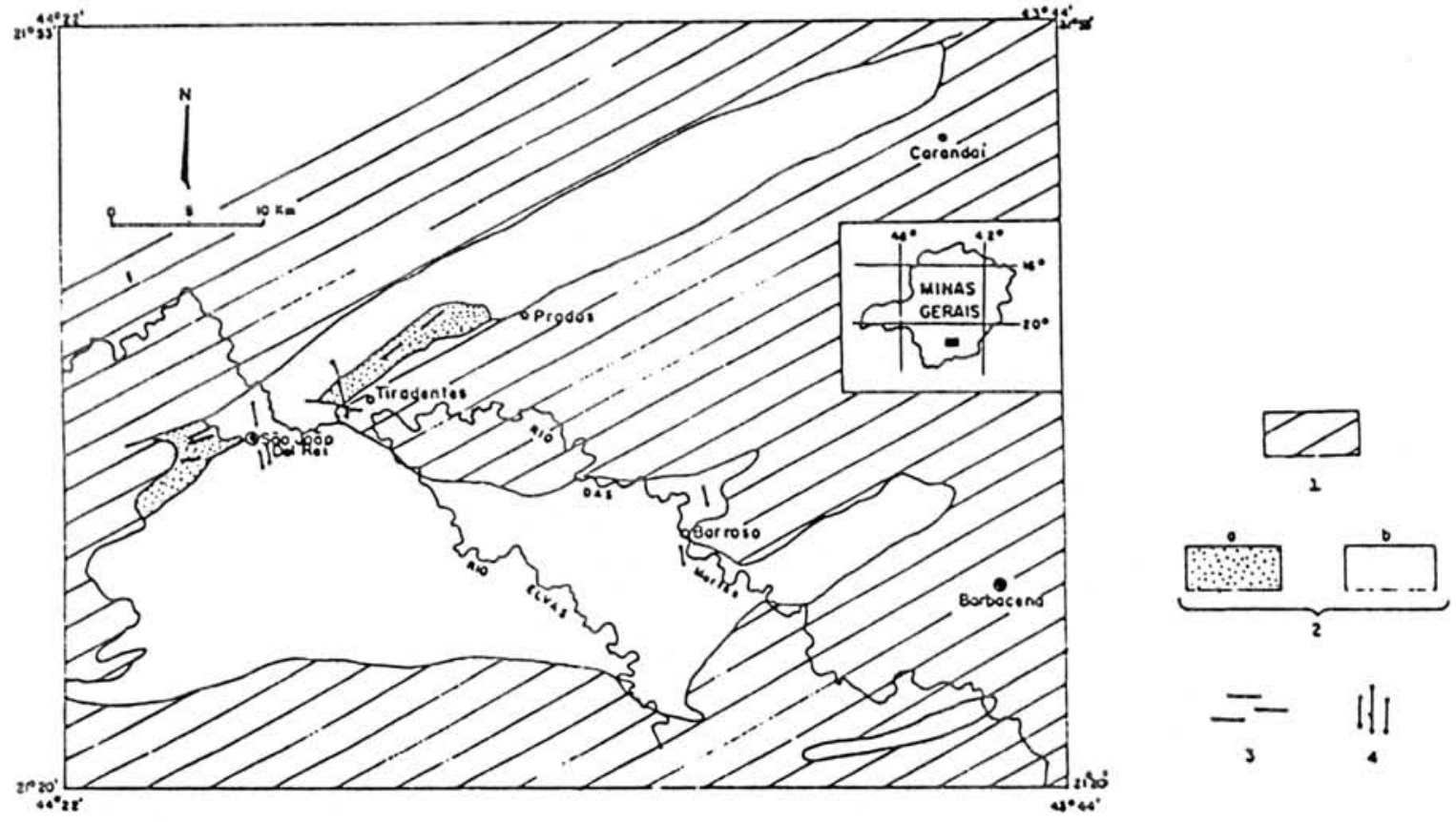

Figure 1 - Location of mafic dykes.

Explanation: 1. granite-greenstone basement; 2. São João del Rei Group, a. Tiradentes Formation (quartzites, metaconglomerates, phyllites), b. Prados and Rio Elvas Formations (phyllites, marbles, quartz-biotite schists); 3 . schistose dykes; 4. unmetamorphosed dykes.

\section{UNMETAMORPHOSED DYKES}

These dykes crop out near São João del Rei, Tiradentes and Barroso. They can be several kilometers long and up to 20 meters wide, oriented N-NW. Their igneous mineralogy and texture are well preserved. The rock is dark gray, medium to fine grained, at places exhibiting amygdales filled with argillaceous material. One of the dykes occupies a fault in the southwestern São José Range. Although completely weathered, it shows a typical porphyritic and amygdaloidal texture.

In thin section the mafic rocks exhibit an intergranular holocrystalline texture and are composed of plagioclase and clinopyroxene. Plagioclase grains are acicular, twinned and at times 
zoned; they can be partially altered to saussurite. Dykes from the São João del Rei region can show primary dark-green hornblende and fine olivine crystals, as well as secondary biotite. Sphene, opaque minerals (including ilmenite), and apatite are frequent, the latter forming inclusions in plagioclase. $\mathrm{Ti}$ and $\mathrm{P}$ enrichment is demonstrated by whole-rock analyses (Table 1). There is also enrichment in $\mathrm{K}, \mathrm{Ba}$, $\mathrm{Sr}$ and $\mathrm{Zr}$, in comparision with average abundances in continental tholeites . CARMICHAEL et al. (1974) investigated continental tholeiites from the Karroo Basin, South Africa, which present chemical characteristics similar to the samples of the present study. A possible explanation for the differences with respect to the normal chemistry of continental tholeiltes is the contamination of the rocks by crustal material.

EBERT (1957) considered the unmetamorphosed dykes to be of Mesozoic age, but radiometric ages are not available. These dykes are emplaced in a fracture system parallel to goldbearing quartz veins. This tensional fracture system is related to the main deformation phase in the São João del Rei Group. In this case, one cannot rule out the possibility that the dykes could have been

Table 1 - Chemical whole-rock analyses of unmetamorphosed-type dykes. 1, 2 - Barroso region dykes; 3, 4 São João del Rei region dykes. Oxides in percentage, elements in ppm.

*.Loss of ignition not determined.

$\begin{array}{lrrrr} & 1 & 2 & 3 & 4 \\ \mathrm{SiO}_{2} & 46.95 & 50.50 & 50.43 & 50.11 \\ \mathrm{THO}_{2} & 3.81 & 3.59 & 3.82 & 3.96 \\ \mathrm{~A}_{2} \mathrm{O}_{3} & 13.78 & 13.75 & 13.74 & 13.40 \\ \mathrm{FeO} \mathrm{Fe}_{2} \mathrm{O}_{3} & 15.20 & 13.67 & 14.72 & 14.22 \\ \mathrm{MnO}_{2} & 0.21 & 0.16 & 0.19 & 0.19 \\ \mathrm{MgO} & 4.50 & 4.49 & 4.59 & 4.56 \\ \mathrm{CaO} & 8.25 & 7.74 & 7.97 & 7.76 \\ \mathrm{Na}_{2} \mathrm{O} & 2.33 & 1.41 & 2.91 & 2.58 \\ \mathrm{~K}_{2} \mathrm{O} & 2.04 & 1.29 & 1.87 & 2.02 \\ \mathrm{P}_{2} \mathrm{O}_{5} & 1.25 & 1.26 & 0.62 & 0.61 \\ - & 98.60 & 97.90 & 100.86 & 99.41 \\ & & & & \\ \mathrm{Ba} & 797 & 658 & 590 & 551 \\ \mathrm{CO} & 24 & 28 & 26 & 39 \\ \mathrm{Cr} & - & 23 & 24 & 13 \\ \mathrm{Ni} & 10 & - & 34 & 80 \\ \mathrm{Rb} & 31 & 62 & 34 & 35 \\ \mathrm{Sr} & 1302 & 1003 & 632 & 615 \\ \mathrm{~V} & 325 & 326 & 333 & 390 \\ \mathrm{Zr} & 237 & 258 & 184 & 249\end{array}$


emplaced in the Proterozoic in a post-deformational stage.

According to QUÉMÉNEUR (1989) intrusive mafic dykes in the Tabuöes granite of the Bom Sucesso region are cut by pegmatitic and aplitic veins which are related to late phases of granite crystallization corresponding to an age around 1,930 Ma. Field evidence indicates that the São João del Rei Group is younger than the Transamazonian granitic intrusions. Therefore, it is clear that at least one period of mafic dyke intrusion took place previous to the deposition of the São João del Rei Group.

\section{REFERENCES}

CARMICHAEL, I.S.F.; TURNER, F.J.; VERHOOGEN, J. (1974) Igneous Petrology. New York, McGraw-Hill. 739p.

EBERT, H. (1957) Aspectos da geologia de São João del Rei. Publicação da Sociedade Brasileira de Geologia, (12):1-71.

KARFUNKEL, J.; NOCE, C.M.; MONTEIRO, A.M.F. (1984) Nota sobre as ocorrências aurfferas de São João del Rei, Minas Gerais. In: CONGRESSO BRASILEIRO DE GEOLOGIA, 33., Rio de Janeiro, 1984. Anais. Rio de Janeiro, SBG. V.8, p.3997-4005.

QUÉMÉnEUR, J.J.G. (1989) Proterozoic dikes of the Bom Sucesso Region, Minas Gerais, Brazil. Boletim IG-USP, Série Científica, 20:31-32.

VALERIANO, C.M. (1985) Geologia estrutural e estratigrafia do Grupo São João del Rei na região de São João del Rei, MG. Rio de Janeiro, 98p. (Tese de Mestrado - Instituto de Geociências/UFRJ). 